\title{
A LIÇÃO DE BARTHES: A ARGUMENTAÇÃO \\ EM SERMÃO DA SEXAGÉSIMA: BREVE ANÁLISE.
}

PIRES, Elisa Tavares ${ }^{10}$

\section{INTRODUÇÃO}

Um sermão é um texto em prosa, um discurso importante, objetivando a propaganda e a edificação religiosa e, exatamente por isso, elaborado de maneira demorada. Conforme Almeida, essa modalidade literária faz parte da oratória, isto é, a arte do bem dizer "empreendendo os recursos verbais com o objetivo de ensinar, persuadir e comover." (ALMEIDA, 2008, p.9)

Alguns teóricos classificam as peças de oratória em quatro tipos: (1) acadêmico, constituído por agrados ou homenagens, também chamado de panegírico; (2) judiciário, aquele que acusa ou defende; (3) político, que trata de questões públicas; e (4) religioso, cuja função é discutir dogmas com vistas a suscitar nos ouvintes devoção a estes mesmos dogmas. A oratória de caráter religioso compõe-se de textos que podem ser subclassificados e acordo com sua função: a homilia, que é a explicação de um tema ou de uma passagem evangélica; o panegírico, que é uma oração de louvor; a oração fúnebre; e, por fim, nosso objeto do estudo, o sermão, também chamado de prédica. Geralmente o discurso oratório composto pelas seguintes partes: a) exórdio ou princípio; b) desenvolvimento; c) peroração; d) conclusão ou epílogo.

Sermão vem do latim, sermone, e originariamente significa conversação. O significado do termo evoluiu para um discurso religioso, pregado geralmente no púlpito. Chama-se prédica porque se desenvolve a partir de um conceito predicável, ou seja, que é

\footnotetext{
${ }^{10}$ Especialista em Língua Portuguesa, formada pela UERJ. Mestranda em Língua Portuguesa, na UERJ, sob a orientação da professora doutora Vania Dutra - (UFF-UERJ). Membro do Grupo de Pesquisa SELEPROT.
} 
possível de ser pregado. Esse conceito predicável é um texto bíblico que o orador comenta de acordo com o tema e as teses que se propõe a desenvolver. Ainda de acordo com Almeida,

O discurso de Vieira, normalmente proferido do púlpito, a partir do texto bíblico, pretende conter a verdade de uma tradição compartilhada. Exemplo de sedução e argumentação, de um árduo e incessante trabalho com a linguagem, o sermão veículo dotado de regras próprias, com reconhecida tradição - dirige-se a um auditório particular, numa circunstância conjuntural precisa, em determinada situação. (ALMEIDA 2009, p.9).

Sob esse ângulo, pautamo-nos na premissa de que é simplesmente impossível entender a ação de Padre Antonio Vieira se não estivermos ambientados em seu contexto histórico. Assim, é preciso estabelecer os vínculos necessários entre o momento em que o texto foi produzido e a construção de seus sentidos. A escolha d'Os Sermões - especificamente o da Sexagésima - se deve ao fato destes serem considerados as obras primas do estilo de Vieira, além de serem o melhor exemplo do barroco conceptista, nos quais o autor trabalha diferentes ideias e conceitos, produzindo uma prosa com períodos construídos de uma maneira extremamente trabalhada, como é possível perceber mesmo em uma breve leitura do sermão. É preciso notar que Vieira era muito seguro de seu discurso e que o tecia utilizando outros textos - bíblicos e teológicos - para legitimar sua fala, mesclando-os, em alguns momentos pertinentes, para validar seus argumentos e garantir que sua intenção fosse cumprida.

Vejamos, então, quem foi Padre Antonio Vieira. Nascido em Lisboa em 1608, Vieira veio para o Brasil ainda criança, em 1615, instalando-se com a família em Salvador. Seu destino na Bahia foi o Colégio dos Padres Jesuítas. De acordo com Clóvis Bulcão em seu livro Padre Antônio Vieira - um esboço biográfico, nos primeiros anos, por mais que se dedicasse, era um aluno apenas mediano, sem 
conseguir um bom rendimento (BULCÃO, 2008, p.27). Em determinado momento, porém, ainda de acordo com o historiador, após um estalo, seguido de uma forte dor de cabeça, Vieira tornou-se um dos estudantes mais capazes do colégio. Com o sucesso acadêmico, veio a vontade de entrar para a Companhia de Jesus.

Toda a obra de Vieira, seus planos e sua visão política se baseavam na Bíblia. Ainda de acordo com Bulcão, na época da restauração portuguesa com D. João IV, em 1640, partiu da Bahia para Portugal e durante 13 anos atuou como uma espécie de ministro de extrema confiança junto a El-Rei, tendo desempenhado diversas funções políticas e diplomáticas na Europa.

Quando vai morar em Portugal, em 1641, Vieira torna-se extremamente popular. As igrejas em que pregava ficavam lotadas, e as pessoas extasiavam-se com seus sermões. Porém, desgostoso do rumo político que Portugal havia tomado regressa ao Brasil alguns anos mais tarde.

O Sermão da Sexagésima, portanto, foi pregado na Capela Real de Lisboa, em 1655, a um auditório constituído em sua maioria por pregadores dominicanos, adversários filosóficos dos pregadores jesuítas. O objetivo principal do sermão era, portanto, atingir os provisores do Santo Ofício, que tanto perseguiam o próprio Vieira, e eram pregadores de estilo rebuscado complexo, o que dificultava 0 entendimento por parte dos ouvintes.

A referência procede. Sabe-se que o Barroco tinha como missão expandir a fé cristã católica e repreender todo tipo de heresia. Dessa forma, esperava-se que os pregadores fossem capazes de ensinar e converter as pessoas. Entretanto, o que estava acontecendo não era isso. A verdadeira finalidade a que se destinava a pregação, isto é, admoestar, ensinar e converter as pessoas, vinha desvirtuando-se do púlpito para uma manifestação exterior e mais festiva de culto.

É preciso perceber que, na época, em Portugal, em pleno apogeu do Barroco, o sermão religioso se havia tornado um dos 
maiores espetáculos artísticos e literários, constituindo-se "uma atividade especial no quadro das atividades religiosas" (CARVALHO, 2000, p.18)

Convivendo com a cultura artística do Barroco, o trabalho de Vieira não poderia deixar de apresentar marcas deste estilo de época, embora com traços bastante peculiares. O que é necessário perceber é que, no Sermão da Sexagésima, Vieira critica os exageros do Barroco e os culpa pelo insucesso das prédicas, afirmando que a responsabilidade pela não frutificação da palavra de Deus está também nos pregadores presos à forma e ao estilo rebuscado e de difícil compreensão; nos que não pregam com o uso da razão e dos exemplos; e nos que privilegiam a vaidade ao arrazoamento no uso da palavra.

Partindo desse fato, objetivamos abordar as questões argumentativas nos sermões de Padre Antonio Vieira, em específico no Sermão da Sexagésima, os quais, mais que textos pertencentes à literatura, têm caráter explicitamente argumentativo, com objetivos claros de convencimento de seus interlocutores. A motivação inicial deste trabalho foi um estudo inicial da produção verbal de Vieira, que permitiu perceber_em suas escolhas gramaticais, não apenas objetivos claros, mas também abundância de estratégias argumentativas destinadas ao convencimento de seu interlocutor (ou se seus auditórios). Além disso, intencionamos fazer do texto literário um objeto de análise linguística na escola. Pensamos ser útil analisar trechos juntamente aos alunos, para mostrar-lhes como estão dispostas algumas marcas linguísticas da argumentação e ensinarIhes a utilizá-las em seus próprios textos.

Percebendo a riqueza de sua obra e o campo fértil para estudarmos as premissas da argumentação, analisaremos, pois, neste trabalho, a prédica de Antonio Vieira pelo esquema proposto por Ingedore Koch, presente no livro Argumentação e Linguagem (2002), tendo como objetivo principal o estudo do sermão fora do 
contexto das aulas de literatura, mostrando que um texto - mesmo literário - com estrutura argumentativa plena, clara, de fácil decomposição em seus elementos formantes, serve como exemplar de estratégias de persuasão para os alunos do Ensino Médio.

\section{QUADRO TEÓRICO}

Trabalhar com a linguagem, cujo estudo exige um horizonte capaz de produzir sentido e não somente uma simples descrição de um fenômeno empírico é considerar que essa não é transparente. Mais que significados, as palavras têm utilizações. O significado de um signo "depende das relações entre as diferentes partes dos enunciados e essas relações são determinadas pela estrutura do sistema da Língua" (Collado 1980: 70).

O texto argumentativo, pela natureza dos fins a que serve, tem como objetivo conseguir a adesão do enunciatário à tese do enunciador. A sua eficácia, consequentemente, depende da adoção, por parte do enunciador, de uma estratégia argumentativa adequada ao conteúdo selecionado e às características biopsicossociais do enunciatário.

De acordo com Koch (2002, p.19), "o ato de argumentar, isto é, de orientar o discurso no sentido de determinadas conclusões, constitui $\mathrm{o}$ ato linguístico fundamental, pois a todo e qualquer discurso subjaz uma ideologia". A neutralidade não existe de fato, pois mesmo aquele discurso que se pretende neutro já contém a sua ideologia.

Assim, conforme Orlandi, compreender um texto não é simplesmente decodificar frases: é passar de uma sucessividade a um todo de sentido, coesivo e coerente (1996).

A interação social por intermédio da língua caracteriza-se pela argumentatividade. Koch, (2002a,_p.10) defende a proposta de Perelman (1970) de que o ato linguístico fundamental é o ato de 
argumentar. Para a autora, "o ato de argumentar é visto como o ato de persuadir que procura atingir a vontade, envolvendo a subjetividade, os sentimentos, (...) buscando adesão e não criando certezas" (grifo da autora). De acordo com Perelman, enquanto o ato de convencer se dirige somente à razão por meio de provas objetivas, $O$ ato de persuadir procura atingir a vontade dos interlocutores, por meio de argumentos plausíveis, e tem caráter "ideológico, subjetivo, temporal, dirigindo-se, pois, a um 'auditório particular'"(KOCH 2002a, p.20). Enquanto o primeiro leva a certezas, o segundo conduz o auditório à adesão dos argumentos a partir das inferências.

\subsection{ARGUMENTAÇÃO}

A argumentação se desenvolve em função de um destinatário, que influencia direta ou indiretamente a forma como evoluem os argumentos propostos. Argumentamos para persuadir alguém que, à partida, não partilha os mesmos pontos de vista ou as mesmas convicções que nós possuímos. Sem ferir a atenção do destinatário da argumentação, isto é, sem fazer com que o interlocutor tenha a sua atenção voltada para o assunto tratado, a persuasão jamais poderá ser efetiva.

Segundo Koch, a enunciação faz-se presente no enunciado por diversas marcas; e seria por meio delas que se chegaria ao alvo para o qual esse enunciado aponta. Não bastaria conhecer o significado literal das palavras: seria preciso reconhecer os seus empregos possíveis, que podem variar de acordo com as intenções do falante e as condições em que o discurso foi produzido.

A ideologia transita entre os espaços da enunciação e da interação de modo que, no momento da enunciação, serão impressos na mensagem os princípios ideológicos que regem determinado veículo, e, no momento que o interlocutor receber a mensagem, ela 
será interpretada segundo os preceitos por ele aceitos. Assim, "por meio do discurso - ação verbal dotada de intencionalidade - tenta influir sobre o comportamento do outro ou fazer com que compartilhe determinadas opiniões" (KOCH, 2002, p.19).

Partindo então, do postulado de que a argumentação é inerente ao uso da linguagem, pode-se adotar as ideias de que argumentar constitui a atividade que estrutura todo e qualquer discurso e de que toda a atividade de interpretação presente no cotidiano da linguagem fundamentar-se-ia na suposição de que quem fala tem determinadas intenções ao comunicar-se $\left(\mathrm{KOCH}_{1} 2002^{\mathrm{a}}\right.$, p.24). Ora, se está presente em "todo e qualquer discurso", pode também ser encontrada em um texto que é supostamente apenas literário.

Entendendo que os sermões do padre Antonio Vieira possuem objetivos claros de convencimento de um auditório, tomamos como base para o Sermão da Sexagésima o esquema de análise de textos também proposto por Koch em seu livro "Argumentação e Linguagem", no qual a autora faz um sumário das categorias analíticas utilizadas nas análises textuais. São duas: recursos argumentativos presentes no nível linguístico fundamental e recursos retóricos ou estilísticos de segundo nível.

Ao observarmos o Sermão da Sexagésima, pudemos perceber que este poderia ser analisado por todas as categorias descritas por Koch, todavia recortamos nossa análise fixando-nos nos operadores argumentativos. Os operadores argumentativos são, de acordo com Koch, certos elementos da língua, explícitos na própria estrutura gramatical da frase, cuja finalidade é a de indicar a argumentatividade dos enunciados. Introduzem variados tipos de argumentos. As palavras que funcionam como operadores argumentativos são os conectivos, os advérbios e outras palavras que, dependendo do contexto, não se enquadram em nenhuma das dez categorias conhecidas pela tradição gramatical. 
Ocorre que o estudo da obra de Vieira acabou restrito ao universo acadêmico e, mesmo assim, de forma fragmentada. Seus textos ficaram aprisionados nos altos estudos de literatura e filosofia, e nos colégios pouco se explora tão vasto acervo. Quando Pe. Antonio Vieira é apresentado aos estudantes do Ensino Médio, normalmente mostram-se um ou dois trechos do Sermão da Sexagésima para ilustrar a prosa barroca.

Se, porém, por um lado nos é claro que esse Sermão é um excelente exemplo do conceptismo barroco, por outro, é um grave reducionismo reduzi-lo a apenas isso. Apesar de ser um texto analisado apenas literariamente pelas escolas, pode e deve ser explorado pelo viés das estratégias argumentativas. O tratamento literário exclusivo dado aos textos parece buscar uma autonomia para a literatura a qual dispensaria o conhecimento da língua, não se recordando de que a matéria-prima da literatura é a língua e de que textos como o de Vieira podem ser fontes de ricos estudos da potencialidade expressiva do Português. Embora seja necessário distinguir a estrutura de uma peça oratória, destinada a ser falada, de um texto argumentativo escrito para ser lido quase sempre silenciosamente, há uma estrutura de base que se mantém, organizada dialeticamente em três componentes fundamentais: tese, antítese e síntese.

No plano geral, de acordo com Guimarães, a argumentação é vista como a busca da persuasão de um auditório pelo locutor. Ou seja, o texto é "um efeito ideológico da posição do autor" (GUIMARÃES, 2007, p.14).

Segundo Ducrot, (GUIMARÃES 2007, p.25) os textos são orientados argumentativamente. Isso quer dizer que orientar argumentativamente com um enunciado $X$ é apresentar seu conteúdo $A$ como devendo conduzir o interlocutor a concluir $C$. Ou seja, é apresentar $A$ como uma razão para se crer em $C$. Tal esquema fica claro se observarmos como são construídas as estratégias 
argumentativas que conduzem o leitor à conclusão esperada por Vieira no sermão da Sexagésima.

De acordo com Guaranha (2003), Vieira acredita que o texto bíblico, por ter sido inspirado por Deus, é a prefiguração de todas as verdades. Para ele, cada fragmento da Bíblia contém um mistério a ser decifrado. Para isso, o orador desenvolve procedimentos de análise textual. Por meio desses procedimentos, o orador deveria levantar os mistérios contidos nessas particularidades com engenho, partindo dos pressupostos de que há uma relação não convencional entre a palavra e a coisa significada e que ela contém um mistério que precisa ser decifrado; a essência de todas as coisas está contida em sua definição e a reflexão consiste em tornar explícitos os atributos contidos nessa definição.

Apesar de ser um texto explorado - ainda assim aquém das possibilidades que oferece - apenas nas aulas de literatura, está claro que o Sermão da Sexagésima tem como objetivo convencer um público específico de que a palavra de Deus não frutifica por culpa dos pregadores. É a partir dessa premissa que pensamos ser profícuo o trabalho de análise de algumas de suas partes em sala de aula. Ao explorar o texto, percebendo como foi trilhado o caminho do autor em direção ao interlocutor por meio das relações linguísticas, o aluno poderá ver, com mais clareza, como se constrói um texto argumentativo e, a partir disso, estar mais consciente das estratégias que ele mesmo utilizará quando for escrever o seu próprio texto.

\section{O SERMÃO DA SEXAGÉSIMA}

Qualquer ato de enunciação ocorre dentro de um quadro de condições, tais como: a) é realizado por um enunciador, condicionado biopsicossocialmente, movido por uma ou mais intenções; b) acontece em um contexto histórico definido e em determinado lugar; c) refere-se a um mundo (ou a aspectos do mundo) objetivo ou 
subjetivo, representado por uma língua e pelos elementos da situação em que se realiza a enunciação; d) dirige-se a um ou mais enunciatários, igualmente condicionados às condições de produção do discurso.

A habilidade que um enunciador tiver para explorar as virtualidades argumentativas desses constituintes da enunciação, certamente contribuirá para a eficácia de sua produção textual. Ao lermos os sermões, percebemos que Vieira era exímio conhecedor de sua língua. Parte disso se deve a sua formação intelectual jesuítica, a qual fez com que ele percebesse que a palavra pode proporcionar e conter muito mais do que aquilo que ela expõe. Por meio desse conhecimento, Vieira tecia seus textos de uma forma magistral, conduzindo seus ouvintes às conclusões a que queria que chegassem.

O sermão, como texto argumentativo, tem como objetivo levar seus interlocutores a determinados tipos de comportamento, atuando sobre eles de maneira incisiva no que concerne à fecundidade das palavras proferidas. Para tanto, como visto, serve-se o orador da estrutura da argumentação formal, composta basicamente de quatro partes: proposição (parte I); análise da proposição (partes II, III, IV); formulação dos argumentos, ou seja, a evidência (partes V, VI, VII, VIII); e conclusão (partes IX e X).

Está claro, então, que o Sermão da Sexagésima tem como objetivo convencer um público específico de que a palavra de Deus não frutifica por culpa dos pregadores, além de levar seus interlocutores a determinados tipos de comportamento, atuando sobre eles de maneira incisiva no que concerne à fecundidade das palavras proferidas. Nele, o Padre Vieira apresenta sua visão da pregação religiosa, adaptando a seus propósitos muitas das doutrinas dos grandes retóricos da Antiguidade Clássica, como Aristóteles e Cícero, bem como da retórica medieval. A sua concepção de pregação religiosa está nele articulada com detalhes. 
Sexagésima é considerado seu mais importante sermão: uma crítica monumental ao estilo barroco, sobretudo ao Cultismo. Como foi pregado na Capela Real, em Portugal, podemos concluir que, o auditório era particular, composto por católicos da nobreza portuguesa da época. Vieira procura se aproximar do auditório dirigindo-Ihe perguntas que ele mesmo, o autor, responde. O autor procurou no sermão a adesão do auditório à sua tese principal de que, se não havia conversões em massa ao catolicismo na sua época, isso ocorria por culpa dos pregadores de então. Após a apresentação da primeira parte do sermão, o exórdio, tem-se o significado do título e a contextualização da Sexagésima: o domingo no qual foi pregado era, segundo o calendário litúrgico católico em vigor até o Concílio Vaticano II, o penúltimo domingo antes da quaresma ou, aproximadamente, o sexagésimo dia antes da Páscoa.

Ao analisarmos o Sermão da Sexagésima, percebemos Vieira como grande usuário de seu aparato linguístico, em prol da conversão, não só dos gentios, mas também dos próprios pregadores de seu tempo. Ao proferir um sermão metalinguístico, Vieira propõe que a arte de pregar deve ter como objetivo principal a semeadura e a colheita, a persuasão, o convencimento, a salvação das almas. A escolha cuidadosa de termos e a explicação minuciosa de tais escolhas nos apresentam um exímio orador, de linguagem clara, porém extremamente fervoroso, que tinha na palavra de Deus sua matéria prima. Nele, o projeto político não era dissociado do religioso, e a palavra era o principal instrumento para a concretização desse propósito. "A palavra é divina e Deus está na palavra" (CARVALHO 2000, p.131).

Vieira serve-se da estrutura da argumentação formal, composta basicamente de quatro partes: proposição; análise da proposição; formulação dos argumentos, ou seja, evidência; e conclusão. Estrutura essa que deve estar presente em todo texto argumentativo, inclusive nos textos dos alunos, os quais, muitas vezes, não a 
utilizam de maneira correta, muito provavelmente porque não se familializaram com ela.

O tema do Sermão da Sexagésima é a "Parábola do semeador", tirada do Evangelho segundo São Lucas: Semen est verbum Dei. Neste sermão, o Padre Vieira usa de uma metáfora: pregar é como semear. Traçando paralelos entre a parábola bíblica sobre o semeador que semeou nas pedras, nos espinhos (onde 0 trigo frutificou e morreu), na estrada (onde não frutificou) e na terra (que deu frutos), Vieira critica o estilo de outros pregadores contemporâneos seus, que pregavam mal, sobre vários assuntos ao mesmo tempo (o que, para ele, resultava em pregar sobre nenhum), ineficazmente e agradavam aos homens ao invés de pregar servindo a Deus.

Assim se apresenta a parábola do semeador, com suas divisões em forma de alegorias, conforme foi reproduzido por Vieira no Sermão:

\begin{tabular}{|l|l|l|}
\hline $\begin{array}{l}\text { Lugar onde } \\
\text { caiu a } \\
\text { semente }\end{array}$ & Tipos de corações & Destino da palavra \\
\hline Pedras & Duros, obstinados & Seca por não ter raízes \\
\hline Caminho & $\begin{array}{l}\text { Inquietos, ansiosos, } \\
\text { perturbados }\end{array}$ & $\begin{array}{l}\text { É pisada, desprezada, não } \\
\text { Ihe dão atenção }\end{array}$ \\
\hline Espinhos & $\begin{array}{l}\text { Embaraçados com os } \\
\text { cuidados e os } \\
\text { prazeres do mundo, } \\
\text { riquezas }\end{array}$ & É sufocada pelos espinhos \\
\hline Terra boa & Bons & Frutifica \\
\hline
\end{tabular}


Vieira estava interessando em saber o motivo de a pregação católica estar surtindo pouco efeito entre os cristãos. Sendo a palavra de Deus tão eficaz e tão poderosa, pergunta ele, como vemos tão pouco fruto da palavra de Deus? Depois de muito argumentar, conclui que a culpa é dos próprios padres. Eles pregam palavras de Deus, mas não pregam a palavra de Deus, afirma.

Ao observarmos mais atentamente, iremos perceber a existência de uma interlocução inerente ao sermão; isso está ligado ao fato de que ele - como todo texto argumentativo - visa a uma mudança, aspira a criar ou a aumentar o assentimento da plateia à tese proposta. O persuadido, ao dar seu assentimento, muda de atitude, modifica seus valores. E essa mudança está diretamente relacionada à ação. Todo o discurso do jesuíta português está centrado no leitor e no auditório e, em última instância, volta-se para o exercício de convencer o ouvinte a adotar a doutrina pregada. Não por acaso, o interlocutor é aquele que deve captar uma verdade absoluta, impessoal, universal, acima de quaisquer circunstâncias. E mais: para conhecer o mundo, é preciso conhecer o texto divino porque o mundo profano é um conjunto enigmático e duro. A chave para a correta decifração do mundo, para ele, está na leitura da Bíblia, e esta só pode ser efetuada de maneira clara e certeira pelo sacerdote, apoiado no Magistério da Igreja.

Cabe aqui voltarmos ao objetivo principal: mostrar ao aluno que um texto literário pode ser argumentativo e, por meio dessa análise ensiná-lo a construir o seu próprio texto, tomando como exemplo as estruturas argumentativas utilizadas nos textos estudados. Dessa forma, a análise de trechos do sermão em sala de aula seria extremamente proveitosa.

Citemos, por exemplo, o trecho em que Padre Antônio Vieira, ensina que "o sermão há de ser duma só cor, há de ter um só objeto, um só assunto, uma só matéria". 
Há-de tomar o pregador uma só matéria; há-de defini-la, para que se conheça; há-de dividi-la, para que se distinga; há-de prová-la com a Escritura; há-de declará-la com a razão; há-de confirmá-la com o exemplo; há-de amplificá-la com as causas, com os efeitos, com as circunstâncias, com as conveniências que se hãode seguir, com os inconvenientes que se devem evitar; há-de responder às dúvidas, há-de satisfazer às dificuldades; há-de impugnar e refutar com toda a força da eloquência os argumentos contrários; e depois disto há-de colher, há-de apertar, há-de concluir, há-de persuadir, há-de acabar. Isto é sermão, isto é pregar; e o que não é isto, é falar de mais alto. (VIEIRA, 2008, p.15)

É a regra da unidade do discurso persuasivo, presente em todo texto argumentativo eficaz. Ao fazermos com que nosso aluno perceba que também o texto dele deve versar um só assunto, o qual deve ser fundamentado em argumentos consistentes, a coerência de sua redação teria uma considerável melhora.

\section{ANÁLISE DE TRECHOS}

No Exórdio (parte I), apoiado em uma proposição bíblica, tida como inquestionável, o pregador compara o seu trabalho ao do semeador bíblico, utilizando a metáfora de que a semente lançada é a palavra de Deus. Ressalte-se aqui que Vieira parte do pressuposto de que seu auditório compartilha com ele a crença de que a Bíblia é a Palavra Divina, sendo, portanto, não passível de ser posta em dúvida. É por isso que o sermão pode ser nela fundamentado:

"Ecce exiit qui seminat, seminare. Diz Cristo que «saiu o pregador evangélico a semear» a palavra divina. Bem parece este texto dos livros de Deus." (p.1)

A seguir, ele analisa a proposição. Ele deixa claro que, para Cristo, tão importante quanto o ato de semear era o ato de sair e que 
os pregadores serão julgados tanto pelos passos que deram quanto pela semeadura. Observe:

"Mas daqui mesmo vejo que notais (e me notais) que diz Cristo que o semeador do Evangelho saiu, porém não diz que tornou porque os pregadores evangélicos, os homens que professam pregar e propagar a Fé, é bem que saiam, mas não é bem que tornem." (p.2)

Nesse momento, o padre começa a formular a argumentação, apoiado nos dois verbos - sair e semear - citados na Bíblia. A partir de então, o orador passa a estabelecer vínculo direto do texto bíblico com a realidade, por meio de comparações.

"Entre os semeadores do Evangelho, há uns que saem a semear, há outros que semeiam sem sair. Os que saem a semear são os que vão pregar à Índia, à China, ao Japão; os que semeiam sem sair são os que se contentam com pregar na pátria."

Servindo-se de um fato de seu tempo, Vieira consegue mostrar ao seu auditório as palavras de Cristo. Diz ainda que todas as criaturas se armaram contra a empreitada do semeador - as pedras, os espinhos, as árvores e os homens - e que ele próprio havia encontrado a mesma resistência. Entenda-se aqui "resistência" como a Inquisição e os colonos do Maranhão, tendo Vieira empreendido uma luta contra ambos. Mais uma vez, ele atesta a validade da parábola servindo-se de um exemplo concreto, mas que fica subentendido no sermão. Vieira não explicita sua própria luta, parte do pressuposto de que seu auditório sabe o que ele enfrentou. E confirma sua tese utilizando um fato real, acontecido com ele mesmo.

Na primeira parte do sermão, Vieira (2008) compara o pregar dos dominicanos que "semeiam sem sair (...) com mais paço" com o dos jesuítas que "saem a semear (...) com mais passos". A utilização das palavras homófonas "paço" e "passo" cria um efeito estilístico que deixa clara a opinião do autor sobre os pregadores do estilo rebuscado. Lembremo-nos aqui que este sermão foi proferido oralmente, o que deu mais vivacidade ao jogo de palavras. Enquanto 
os dominicanos se fechavam no palácio, os jesuítas saiam pelo mundo a pregar a palavra, o que condizia com o que Cristo pregou: "ide e pregai a toda a criatura".

Na sentença "Os (pregadores) de cá (Portugal), achar-vos-ei com mais passos; os de lá, com mais paços: Exiit seminare", além do conteúdo explícito, os pressupostos são: os Jesuítas se dispunham a sair de seu país e pregar o evangelho "a toda criatura", e aqueles que ficavam, os dominicanos, não seriam merecedores, como os Jesuítas, de maior recompensa por parte de Deus. Note que, no final, o orador resume a proposição aos dois verbos: sair e semear. Como verbo indica ação, fica patente o pragmatismo contido no ideário de Vieira: a maior recompensa caberá a quem praticar mais ações.

É preciso notar o uso frequente das perguntas retóricas, as quais encaminham o leitor para a resposta pretendida pelo autor. Resposta essa que pode ser completamente diferente da expectativa criada no auditório pelas perguntas do orador. O sermão da sexagésima questiona o porquê de as palavras dos pregadores não frutificarem. Ele pergunta "por que hoje não se converte ninguém" (p.19). A pergunta não abre espaço para respostas negativas: é o pressuposto da afirmação. Poderia ser convertida em "hoje não se converte ninguém". Parte-se então da afirmação de que a palavra não frutifica por três possíveis causas, indicadas na terceira parte do sermão: Deus, o ouvinte e os próprios pregadores. Ao fazer perguntas supondo que as causas da falha seriam Deus e os ouvintes, o pregador conduz seu público a uma conclusão, fazendo com que pensem ser esses verdadeiramente os fatores responsáveis pela falha dos sermões. Entretanto, ele mesmo prova que tais causas não seriam os motivadores do não frutificar.

A partir daí, ele trabalha pela exclusão. Deus não falha, isso é um dogma de fé, uma proposição inquestionável, que tanto ele quanto seus interlocutores partilham. "Primeiramente, por parte de 
Deus, não falta nem pode faltar". Afirmando isso, passa para a próxima proposição, dizendo que os pregadores deitam a culpa nos ouvintes. Vieira contra-argumenta e prova seu ponto de vista, mais uma vez, tomando como base o Evangelho. O trigo caiu entre espinhos, pedras e no meio do caminho. Nos espinhos, afogou-se; nas pedras, secou-se; à beira do caminho, foi pisado. "Isto é o que diz Cristo; mas notai o que não diz". Ao chamar atenção dos ouvintes para aquilo que Cristo não disse, mas está implícito em sua fala, Vieira utiliza um recurso argumentativo (manobra argumentativa) que apresenta como se fosse pressuposto justamente aquilo que se está querendo veicular como informação nova. Essa informação seria que o trigo nunca deixou de frutificar por falta de sol ou chuva, ou seja, por culpa do céu. O trigo não frutifica pela dureza do caminho ou pela frieza das pedras. Mesmo assim, ele nota que o trigo, apesar de não frutificar, nasceu. "Nasceu até nos espinhos (...); nasceu até nas pedras." Analogamente, a palavra também nascerá em qualquer coração em que cair. Infere-se, então, que a culpa não pode ser dos ouvintes, mesmo daqueles que possuem um coração infértil. Percebase aqui o "até", um operador discursivo que seleciona o argumento mais forte da escala orientada para a conclusão. No caso, para Vieira, o fato de a palavra nascer sempre, comprovando que a culpa não pode ser nem do ouvinte nem de Deus.

É interessante notar que, neste ponto do sermão, os ouvintes chegam à mesma conclusão que Vieira, de forma bastante natural, consequência da construção primorosa dos argumentos do locutor.

Eliminando Deus e os ouvintes como os responsáveis por essa falha, o padre conclui que a culpa é, então, dos pregadores e disso, ele não se exime. 
E se a palavra de Deus até dos espinhos e das pedras triunfa; se a palavra de Deus até nas pedras, até nos espinhos nasce; não triunfar dos alvedrios hoje a palavra de Deus, nem nascer nos corações, não é por culpa, nem por indisposição dos ouvintes. Supostas estas duas demonstrações; suposto que o fruto e efeitos da palavra de Deus, não fica, nem por parte de Deus, nem por parte dos ouvintes, segue-se por consequência clara, que fica por parte do pregador. E assim é. Sabeis, cristãos, porque não faz fruto a palavra de Deus? Por culpa dos pregadores. Sabeis, pregadores, porque não faz fruto a palavra de Deus? -- Por culpa nossa. (p.19)

Como já apontou Fiorin, o uso do nós faz com que o eu se dilua, evitando o realce da subjetividade do enunciador. A escolha do pronome seria uma posição "coletiva e assumida por alguém que se coloca como seu porta-voz, mas também como seu participante". (FIORIN, 1996, p.97)

O se é um operador de coordenação semântica, que introduz um novo ato de enunciação. A utilização do "se", em "se a palavra de Deus", faz com que a proposição possua valor concessivo. Pode-se entender se é verdade que NEM Deus NEM os ouvintes têm culpa, então a culpa Só pode ser dos pregadores. No caso, o "se" aponta para a falsidade da proposição antes apresentada, que dizia ser a culpa dos ouvintes ou de Deus. Note-se no trecho acima a utilização do "nem", um operador argumentativo que soma argumentos a favor de uma mesma conclusão. Nesse caso, o fato de que Deus é infalível e de que não são os ouvintes os culpados. Ao dizer que é uma "consequência clara", e afirmando categoricamente que "assim é", Vieira não abre espaço para deduções do público, validando de antemão a conclusão a que chegará o orador.

Concluindo que a culpa é do pregador, em certo ponto de sua análise, Vieira passa a argumentar tentando encontrar a melhor resposta para o questionamento sobre o porquê isso aconteceria, pois os pregadores estavam falando palavras de Deus. Começa então a examinar as causas dessa culpa, sempre terminando suas indagações 
com a estrutura "boa razão é também esta". Interessante perceber que a repetição dessa estrutura ao final de cada proposição mostra que a ineficiência está para além das questões elencadas. Essas parecem ser uma boa razão, mas não são suficientes para a conclusão. Mais uma vez o pregador conduz seus ouvintes a conclusões que serão desmentidas por ele ao longo do texto.

Finalmente, ele conclui: "Sabeis cristãos, a causa porque se faz hoje tão pouco fruto das pregações? É porque as palavras dos pregadores são palavras, mas não são palavras de Deus. (...) Esse é o mal. Pregam palavras de Deus, não a palavra de Deus". Moura Neves (2000) considera que o uso do artigo definido em sintagmas nominais pode denotar que a informação tratada é de conhecimento tanto do falante como do ouvinte. No enunciado do sermão, "o artigo tem muito mais importância do que a preposição e, conforme sabemos pelo próprio aparelho formal da língua, serve para determinar um sentido" (CARVALHO 2000 p.23). Assim, no caso de Vieira, a palavra de Deus seria aquilo que tem significação maior e deveria servir de base e tema para o discurso, não sendo passível de equívocos de sentido. Palavras de Deus, no plural, seriam interpretações, muitas vezes tendenciosas, da palavra primeira, aquela que sempre frutifica, segundo o autor. De acordo com o próprio Vieira, "as palavras de Deus pregadas no sentido em que Deus as disse, são palavras de Deus, mas pregadas no sentido que nós queremos, não são palavras de Deus, antes podem ser palavra do demônio." (VIEIRA, 2008, p.28).

Em certo ponto, Vieira diz: "saiu quem semeia a semear". Note aqui que a escolha do verbo pelo substantivo não se dá ao acaso. É, pois, o próprio Vieira (2008) que explica:

"Entre o semeador e o que semeia há muita diferença. Uma coisa é o soldado, outra coisa o que peleja; uma coisa é o governador e outra, o que governa. Da mesma maneira, uma coisa é o semeador e outra, o que semeia; uma coisa é o pregador e outra, o que prega. 
O semeador e o pregador é nome; o que semeia e o que prega é ação; e as ações são as que dão o ser ao pregador. Ter o nome de pregador, ou ser pregador de nome, não importa nada; as ações, a vida, o exemplo, as obras, são as que convertem o Mundo." (p.19)

O que vale aqui é a ação e não o sujeito. De acordo com Julio Carvalho (2000), o pregar se assemelha ao semear. "O semeador é, ao mesmo tempo, palavra e ação (fala e faz), donde se deduz ser possível pregar falando e pregar agindo" (p.20). O nome, por si só, nem sempre designa uma atividade e, como exemplo disso (exemplo irônico, é preciso notar), diz que nem sempre o governador é quem governa. Quando se diz "quem semeia" sempre se terá uma ação. No entanto, para que alguém se torne verdadeiro semeador, é preciso que realmente pratique a ação designada pelo verbo.

"Oh que grandes esperanças me dá esta sementeira! Oh que grande exemplo me dá este semeador!"

Sobre o ponto de exclamação, Dahlet (2006, p.193) afirma ser este usado com o objetivo de afetar diretamente o interlocutor, pois cria "uma força de interpelação, logo, o impacto almejado por ele reage no sentido previsto pelo escritor". Os dois períodos com valor interjetivo apresentam-se como uma espécie de franca expansão de sentimentos e pensamentos íntimos do autor, como se tivessem sido arrancados do locutor pela situação, como uma espécie de grito. Tais períodos corroboram a tentativa de convencer seus interlocutores da importância da semeadura.

Já os marcadores da interrogação colocam o leitor na posição de interlocutor direto daquilo que o autor pretende como resposta, já que são interativos por natureza. No entanto, devemos notar que, nesse sermão, o uso recorrente de perguntas não lança para o leitor a dúvida suscitada. Observe o trecho abaixo:

"E que faria neste caso, ou devia fazer o semeador evangélico, vendo tão mal logrados seus primeiros trabalhos? Deixaria a lavoura? Desistiria da sementeira? Ficar-se-ia ocioso no campo, só porque 
tinha lá ido? Parece que não. Mas se tornasse muito depressa à casa buscar alguns instrumentos com o que alimpar a terra das pedras e dos espinhos, seria isto desistir? Seria isto tornar atrás? Não por certo." (p.15)

As perguntas feitas são imediatamente respondidas pelo próprio Vieira. Ou seja, ele pretende que seu interlocutor formule respostas para as interrogações propostas e sim, que suas respostas sejam orientadas pela maneira com que ele mesmo as responde. Desse modo, a relação estabelecida entre pregador e público torna-se mais persuasiva e o sermão passa a suscitar uma resposta nos ouvintes, a partir de uma compreensão ativa de concordância e compromisso.

Vieira também diz que o pregador deve pregar a toda criatura, pedras, árvores, animais. E que, da mesma maneira que os apóstolos, aqueles que falam sobre a palavra de Deus haveriam de achar toda a espécie de homens:

"... homens homens, haviam de achar homens brutos, haviam de achar homens troncos, haviam de achar homens pedras." (p.15).

Nesse ponto, a união de dois substantivos em homens troncos e homens pedras, dando uma ideia de adjetivação, cria uma metáfora que retoma o conceito explicitado na parábola do semeador. A palavra de Deus há de cair em todos esses lugares e, se for realmente utilizada em seu verdadeiro sentido, há de frutificar.

Ao observarmos mais atentamente o Sermão da Sexagésima, podemos perceber que o poder expressivo do estilo de Vieira é manifestado, principalmente, pelas metáforas construídas em seus apólogos e da seleção lexical clara, mas nem por isso menos contundente e eficaz. As interrogações e exclamações são outras marcas importantes do discurso vieiriano. 


\section{CONSIDERAÇÕES FINAIS}

Analisar um texto literário de estrutura argumentativa pelo viés da argumentação é fundamental não apenas para que o aluno perceba as nuances do texto, mas também para que ele entenda como as ideias devem ser organizadas com vistas a persuadir o leitor, transmitindo um ponto de vista.

Isso fará com que ele perceba que, independentemente do assunto que se está abordando ou do século em que se encontra, a todo discurso subjaz uma ideologia e uma estrutura argumentativa que possibilita a veiculação dessa ideologia através de uma mensagem composta de forma eficientemente clara.

Segundo Guaranha,

toda leitura proposta em sala de aula precisa dar oportunidade ao aluno de criar, dialogar com o autor. É bom que todo exercício de leitura seja direcionado para 0 ato criador. Quando o aluno descobre que é capaz de interagir com alguém que viveu séculos antes dele, quando percebe que é possível vincular a realidade da obra com a sua realidade, então ele se interessa pelo texto. Para isso, é necessário que o professor trabalhe variedade e qualidade, propiciando o acesso a um repertório tão vasto quanto possível. (GUARANHA, 2003, p.20)

Em sala de aula, tais estratégias podem ser discutidas juntamente aos alunos, enfatizando que eles também podem utilizálas em seus próprios textos. Entendendo que a argumentação é fator primordial em todas as línguas, um estudo esquematizado pode ser construído em conjunto, para que a turma retire do sermão os pontos principais. Além disso, os alunos poderiam pesquisar o momento em que o sermão foi proferido para entenderem que não se deve desvincular o texto de sua condição de produção. Dessa forma, passariam a pensar melhor sobre o que iriam escrever, valendo-se da 
utilização de alguns operadores discursivos, por exemplo, de maneira mais consciente para a construção de sua própria argumentação.

Não há como esgotar um trabalho com os sermões, visto a vastidão interpretativa que esses nos oferecem. Nosso objetivo foi elencar alguns exemplos que demonstrassem a habilidade desse arguto pregador e os efeitos que essas escolhas produziram no texto. O que podemos dizer, além de tudo isso, é que Vieira fez um grande bem à língua portuguesa, deixando como herança uma profícua produção textual, tanto de caráter retórico quanto religioso, profético, literário e político, produzindo na nossa língua como se essa fosse a língua na qual Deus desejava ouvir sua Palavra e ver ação desta Palavra nos homens.

\section{REFERÊNCIAS}

ALMEIDA, Marialda de Jesus. A persuasão nas crônicas de Lya Luft escritas na coluna "Ponto de Vista" para a revista Veja. Santo André, SP: 2009.

ASCOMBRE e DUCROT, Apud GUIMARÃES, Eduardo. Texto e Argumentação. Um estudo das conjunções do português. Campinas, SP: Pontes, 4 ed. 2007.

BECHARA. E. Moderna gramática portuguesa. 37.ed. rev. e ampl. Rio de Janeiro: Lucerna, 2004.

BULCÃO, C. Padre Antônio Vieira: um esboço biográfico. Rio de Janeiro: José Olympio, 2008

CARVALHO, J. O tecelão e o tecido. Rio de Janeiro: EdUERJ, 2000.

COLLADO, J.A. Fundamentos de lingüística geral, tradução de Isabel Gonçalves. Lisboa: Edições 70, coleção Signos, 33, 1970.

DAHLET, V. As (man)obras da pontuação: usos e significações. São Paulo: Humanitas. 2006.

FIORIN, J. L. As astúcias da enunciação. 1.e.d São Paulo. Ática. 1996

GUARANHA, Manoel Francisco. O Sermão da Sexagésima e o processo argumentativo: estratégias de trabalho em classe. [s.l.]:[s.n.],s/d. 
$\mathrm{KOCH}$, Ingedore. Argumentação e Linguagem. 7a. ed. São Paulo: Cortez, 2002.

MOURA NEVES, M.H. Gramática de usos do português. São Paulo: Unesp, 2000.

ORLANDI, E. Análise do discurso: princípios e procedimentos. São Paulo: Pontes, 1996.

VIEIRA. A. Sermões I. Direção: Pe. Gabriel C. Galanche, SJ e Pe. Danilo Mondoni. São Paulo: Edições Loyola, 2008 